меньшего, чем конечное число ряда; определение в легенде реального начального и конечного чисел ряда; определение в легенде верхней и нижней границ интервалов, идущих один за другим.

Усовершенствована модель взаимодействия автоматических и интерактивных методов образования шкал количественных показателей с учетом определенных особенностей их разработки для создания тематических карт.

Ключевые слова: шкалы количественных показателей, тематические карты, методы образования шкал, непрерывная шкала, условно-непрерывная шкала, ступенчатая шкала, "умная картография", числовой ряд, географические информационные системы.

E. Bondarenko, Doctor of Science in Geography, Professor

Taras Shevchenko National University of Kyiv, Kyiv, Ukraine

\title{
SPECIFIC ASPECTS OF SCALES FORMATION ON THEMATIC MAPS IN CONDITIONS OF CARTOGRAPHY COMPUTERIZATION
}

The article is devoted to the consideration of specific aspects of scales formation on thematic maps in modern conditions of automation of cartographic works. The special aspects are revealed by systematization of the functionality of the software, which relates to geographic information systems (GIS).

The author summarized the existing knowledge regarding the development of scales for cartographic image methods, which provide their using in the practice of thematic mapping. The classification of scale formation methods is presented according to the degree of automation with distribution: automatic methods for distributing numerical series by gradation (including using "smart cartography") and interactive (user-defined), which improve and expand the automatic. Two groups of cartographic image methods are identified depending on the degree of accuracy in the display of objects, phenomena or processes (geometrically accurate and schematic), which imply the use of scales. The factors of scales development (nature of mapping phenomena affecting the choice of the image method, the purpose of the map, the definition of its completeness and accuracy, the quality of the source data, the geographical specificity of the territory) are defined.

The author formulated the principles for the formation of algorithms for calculating numerical intervals of graded scales, as well as the possibilities of "smart cartography" for the development of their continuous analogues. Additional techniques are proposed for interactive distribution of the number of series at intervals: the rounding the boundaries of intervals; the choice of the initial round number more than the initial number of the series; the choice of a round finite number less than a finite number of the series; the definition in the legend of the actual starting and final numbers of the series; the definition in the legend of the upper and lower bounds of the intervals are following one after another.

In this article the author improved the model of interaction between automatic and interactive methods of scales forming based on certain features of their development for creating of thematic maps.

Keywords: scales of quantitative indicators, thematic maps, methods of scales formation, continuous scale, conditional continuous scale, interval scale, smart cartography, numerical series, geographic information systems.

О. Томченко, канд. техн. наук, наук. співроб.

ДУ "Науковий центр аерокосмічних досліджень Землі Інституту геологічних наук НАН України", Київ, Україна,

Л. Мазуркевич, учитель географії,

О. Малець, учень 11 класу, дійсний член МАН Русанівський ліцей, Київ, Україна, КПнЗ "Київська Мала академія наук учнівської молоді", Київ, Україна, І. Підлісецька, канд. геогр. наук, асист. Київський національний університет імені Тараса Шевченка, Київ, Україна

\section{ДОСЛІДЖЕННЯ ДИНАМІКИ ЗМІНИ ПЛОЩ ОСТРОВІВ київської групи РІчки днІпро}

Дослідження полягає у відтворенні історичного вигляду островів Київської групи Дніпра на основі використання матеріалів аерокосмічного знімання часів Другої світової війни і сучасних космічних знімків із застосуванням геоінформаційних технологій (ГІС). За допомогою ГІС та методів дистанційного зондування (ДЗ3) установлено суттєві зміни площі островів Київського архіпелагу в період із 1942 до 2017 р. Визначено, що острови почали зменшуватись унаслідок антропогенних змін (намивання піску), що негативно вплинуло на стан їх біотопів. Робота присвячена аналізу зміни площ островів Київської групи Дніпра (16 найбільших островів) та околиць за 75 років, а також детальному вивченню ландшафтної структури острова Великий Північний та його острова - супутника Пташиний, що виник не так давно і продовжує інтенсивно формуватися. Створено детальну картографрічну схему ландшафтів о. Великий Північний та розроблено нову екологічну стежку.

Ключові слова: дослідження динаміки островів Київської групи Дніпра, геоінформаційні технології, картографічна схема, ландшафтна структура, екостежка.

Постановка проблеми. Цінність островів Києва та околиць як складової Дніпровського екологічного коридору полягає в унікальності ландшафртно-біоценотичних формацій [3]. Справа в тому, що типові біотопи річкової заплави на островах збереглися набагато краще, ніж на сусідніх берегових ділянках у межах Києва. При цьому стан порушених антропогенним впливом острівних ландшафтних угрупувань ще не є безнадійним і може бути відновлений у випадку встановлення заповідного режиму. У сучасних умовах, коли природа Києва зникає просто на очах, для того щоб зрозуміти, що ми втрачаємо, необхідно чітко собі уявити, якою була природа цього куточка Дніпра до розвитку тут міста, якою вона була ще навіть порівняно недавно. Це можливо з використанням сучасних геоінформаційних технологій і архівних картографічних та аерокосмічних матеріалів, що доводить подана робота.

Аналіз останніх досліджень і публікацій. Виходячи з аналізу літератури, зрозуміло, що Дніпро та його ділянка біля Києва неодноразово перебувала в полі зору багатьох дослідників. Підготовлені інженером М.I. Максимовичем зведення "Днепр у гор Киева. Краткий гидрографический и исторический очерк" (1898) та "Днепр и его бассейн: История и гидрография реки" 
(1901) присвячені гідрографії Дніпра, але містять мало інформації про прибережні урочища й острови. Природі Київських островів також було присвячено узагальнюючу працю Міжвідомчої лабораторії основ заповідної справи під керівництвом академіка Т. Л. Андрієнка детальний проект створення регіонального ландшафтного парку "Дніпровські острови", а також дисертаційне дослідження їх фрлори, виконане Г. Цукановою [9], але цілісного краєзнавчого дослідження київського архіпелагу та прибережних урочищ наразі немає.

Із сучасних робіт важливий внесок зробив B.I. Вишневський [2], який написав книгу за назвою "Дніпро біля Києва", де йдеться про русловипрямні роботи в межах Києва, про зміну київської заплави Дніпра від часів Київської Русі до XX ст.

У 2006 р. з метою незалежної експертизи експедиція ВГО "Чиста хвиля" провела обстеження 35 островів в околицях Києва стосовно їх екологічного значення. Цій самій темі присвячена праця В. А. Онищенка "Острови на Дніпрі у північній та центральній частині Києва". Науковці І. Парнікоза та Ю. Шевченко узагальнили відомості про острови Дніпра у своїй монографрії "Київські острови на Дніпрі - погляд крізь століття" та наголосили про необхідність створення на них заповідної зони [6-7].

Метою дослідження $€$ обґрунтування необхідності запровадження заповідного режиму для островів Київської групи Дніпра, які перебувають під більшим антропогенним впливом, у межах проекту РЛП "Дніпровські острови". Для збереження ландшафтів острова Великий Північний запропоновано екологічний маршрут і розроблено ландшафтну картографічну схему острова Великий на основі застосування геоінформаційних технологій (ГІС) та методів дистанційного зондування Землі (ДЗЗ).

Методичну й теоретичну основу дослідження становлять положення сучасної географічної, біологічної й картографічної науки в галузі тематичного картографування. Обґрунтування теоретичних положень базується на загальнонаукових принципах пізнання дійсності, зокрема на методах спостереження, аналізу й синтезу, класифрікації, аналогії, системного підходу.

У процесі виконання роботи застосовано метод картографічного моделювання 3 урахуванням сучасного геоінформаційного забезпечення і методів ДЗ3. Інформаційну базу дослідження зібрано та сформовано особисто авторами на основі аерокосмічних матеріалів, картографічних і літературних джерел.

Недостатньо дослідженими, на нашу думку, є вплив антропогенних передумов на формування заплави Дніпра. Особливо мало досліджена зміна площі островів у зоні сучасної активної розбудови Києва. Мало описано використання ГІС-технологій для дослідження Київських островів. Збереження унікальних природних комплексів заплавних островів $€$ актуальною природоохоронною проблемою міста Києва та під час проведення дослідження пропонуємо шляхи вирішення цієї проблеми.

Виклад основного матеріалу. Берегова лінія Києва почала інтенсивно змінюватися останні 100 років через стрімке розростання міста та його перепланування. До цього дніпровську заплаву в Києві формували льодовики і це стало основою заплави Києва на довгі часи. Найбільше на зміну ландшафту прибережної частини Києва вплинули русловипрямні роботи XIX ст. У зв'язку з будівництвом мостів та розвитком судноплавства відбувалися масштабні заходи з регулювання Дніпра в межах Києва [7].

Починаючи з другої половини XX ст., київські острови знову зазнали суттєвих змін. Це пов'язано з відбудовою міста після Другої світової війни, його розширенням і побудовою Київської ГЕС/ГАЕС. У північній частині Києва було проведено роботи зі створення обвідного каналу 3 київської ГЕС/ГАЕС, яке впадало в основне русло Дніпра. Це суттєво змінило ландшафти північної групи київських островів, а саме: відбулося відокремлення від материка другої частини острова Великий Північний, створення дніпровського рукава Річище та об'єднанням острова Муромця із Трухановим островом. Оскільки друга половина $\mathrm{XX}$ ст. була найактивнішою для формування київської заплави Дніпра, то в нашому дослідженні був розглянутий період із 1942 по 2017 рр.

Картографування історичної реконструкції русла старого Дніпра нами було виконано за архівними німецькими топографрічними картами [11] та аерофотозйомкою часів Великої Вітчизняної війни [1], що дозволило відобразити історичний вигляд русла Дніпра до утворення водосховища. Для визначення сучасного стану русла Дніпра було використано знімки із КА Sentinel-2 сімейство супутників дистанційного зондування Землі Європейського космічного агентства, створеного в рамках проекту глобального моніторингу навколишнього середовища й безпеки "Copernicus". Поєднавши архівні матеріали із сучасними, які були отримані на основі дешифрування сучасних космічних знімків, визначено трансформації заплави Дніпра, які відбулися внаслідок регулювання річки греблею Київської ГЕС.

Програмний комплекс ArcGIS пропонує різноманітний набір можливостей для виконання нашого дослідження - отримання нової інформації про досліджуваний об'єкт, використовуючи інструменти для візуалізації й аналізу наявних даних. Таким чином, за допомогою програми ArcGIS було створено векторні шари - контури берегової лінії київських островів станом на 1942 р. та 2017 р. і після побудови топології було чітко визначено площі островів (рис. 1, 2).

На діаграмі (рис. 2) можна побачити, що більшість островів суттєво зменшили свою площу. Це є пагубним для збереження мальовничих ландшафтів р. Дніпра, оскільки зникає територія для проживання різноманітних видів тварин, що занесені до Червоної книги, наприклад, кулика-сороки, та місць поширення рідкісних рослин, таких, як вовче тіло болотяне, тирлич звичайний, верба розмаринолиста та цінна рослина - валеріана лікарська. Хоча збереження островів Києва є доволі важливим аспектом у сучасній природоохоронній діяльності. 

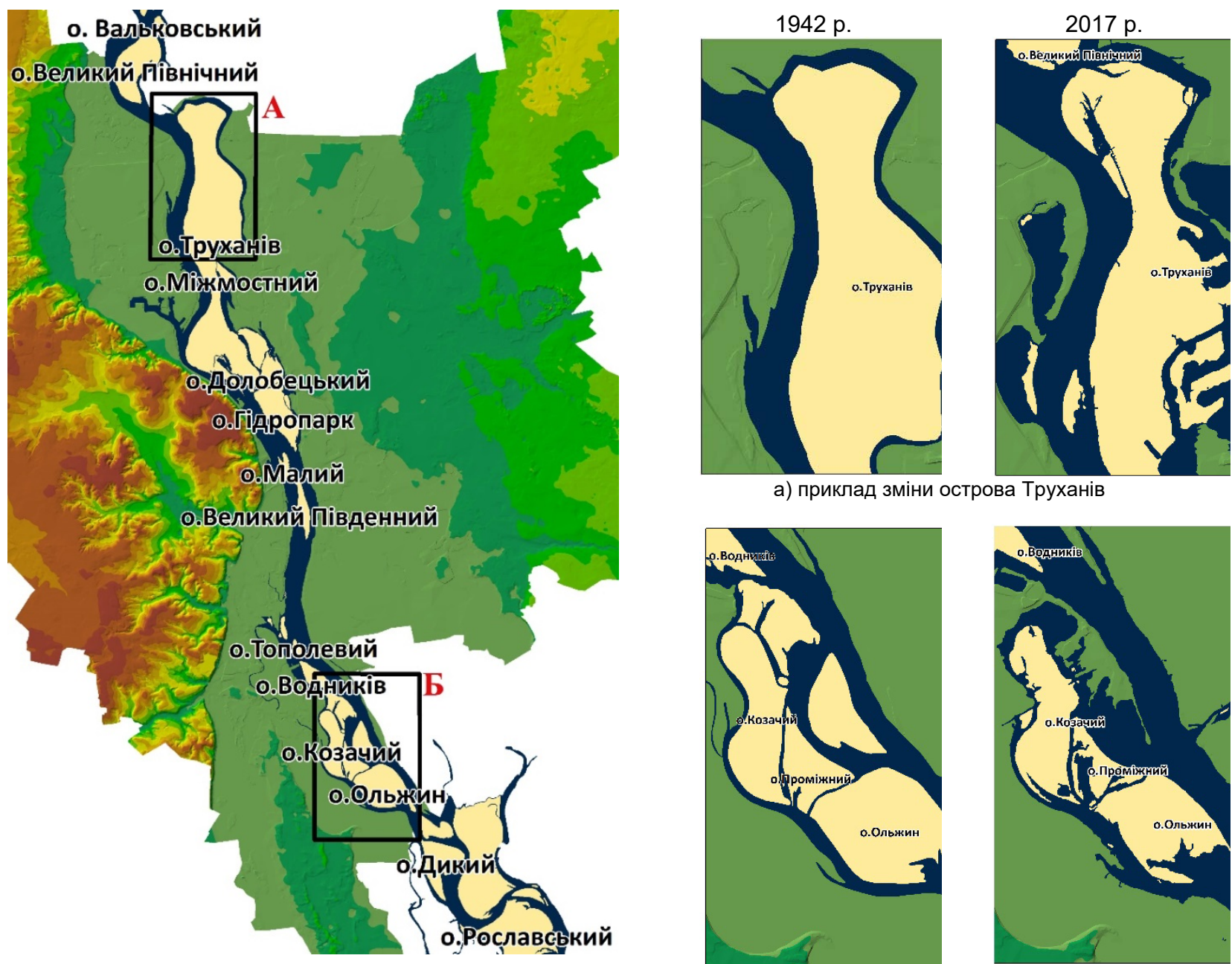

а) приклад зміни острова Труханів
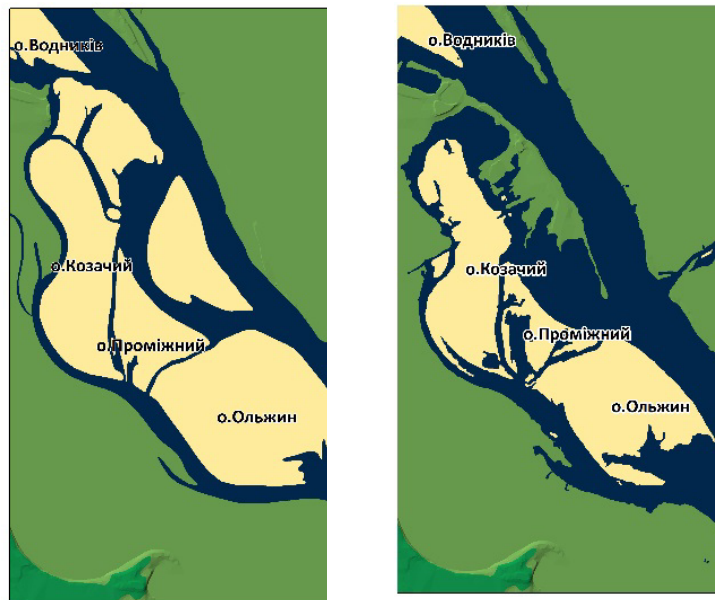

б) приклад зміни південних островів

Рис. 1. Візуалізація історичної реконструкції трансформації заплави Дніпра в межах Києва

Вектор групи Київських островів накладений на рельєф у програмі ArcGis станом на 1942 р. та детальніше наведені території: а) о. Труханів; б) група південних островів Козачий, Проміжний, Ольжин

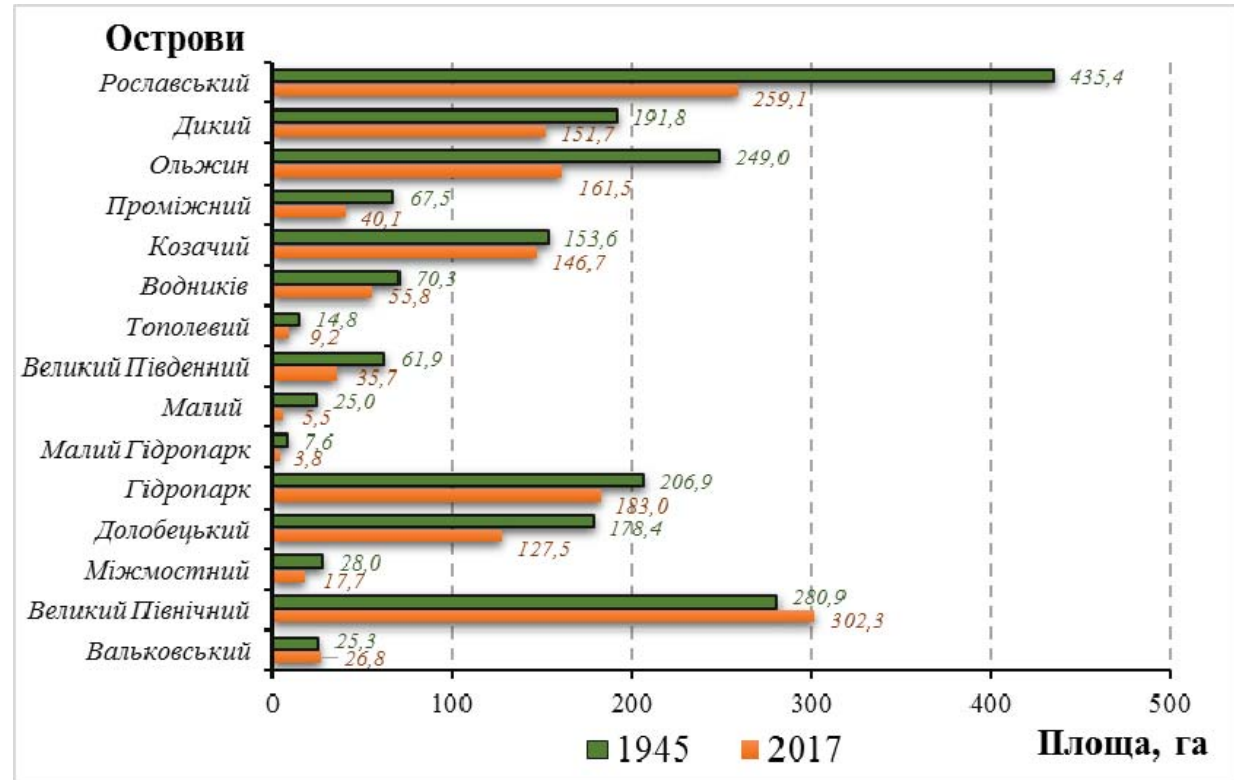

Рис. 2. Динаміка зміни площі Київських островів за 75 років,

отримана на основі дешифрування архівних аерофотознімків та сучасних космічних знімків 
Створення детальної ландшафтної картографічної схеми острова Північний Великий та Пташиний. Представлена робота $є$ продовженням дослідження за темою: "Дослідження динаміки зміни площ дніпровських островів Київської групи та ландшафтів острова Великий Північний" (виконавець О. Малець), виконаного в попередні роки у рамках дослідження Малої академії наук (МАН), яка стосувалася тільки острова Північний Великий та тривимірного моделювання зміни його берегової лінії за 70 років [4]. Наступним етапом дослідження стало детальне вивчення сучасного стану ландшафту острова й розпізнавання його рослинності на основі дешифрування космічного знімку із супутника QuickBird.

У ході аналізу архівних картографрічних творів з'ясовано, що острів Північний Великий сформувався внаслідок відділення від материкової частини лівого берега Дніпра. На сьогодні він складається із двох частин, що були утворені в різний період часу. Перша частина утворилася після проведення русловипрямних робіт під керівництвом М. Максимовича, а друга частина - унаслідок побудови обвідного каналу Київської ГЕС/ГАЕС. Із 70 по 90 роки острів мав стабільну площу, але у 90 роках тут почали видобувати пісок для намиву житлових масивів, тому острів зменшува- вся, що негативно вплинуло на його біоту. Ландшафти острова представлені угрупованнями заплавного лісу, чагарниками, остепненими луками та пісколюбними трав'янистими угрупуваннями.

На початку 2000 років у верхів'ї острова Великий Північній, а саме на північ від нього, з'явився острів алювіального походження. Майже весь острів - це колишні неглибокі затоки між мілинами. На сьогодні вони суцільно зарослі водно-болотяною рослинністю, серед яких домінуючим видом є очерет. Острів то з'являвся, то знову зникав, але починаючи із 2013-2014 рр. він має більш-менш сталу площу та стає місцем перебування багатьох водо-плаваючих птахів (за що і отримує назву Пташиний) та рідкісних тварин і рослин [9; 10]. Хоча острів сформувався відносно недавно, але він служить важливою ланкою у тваринному світі, оскільки $€$ стоянкою для перелітних птахів та місцем гніздування місцевих птахів, і ця територія $€$ перспективною для створення заповідної зони.

У результаті використання одного з методів автоматичної класифрікації космознімку отримано тематичну картосхему біотопів/ландшафтів острова Північний Великий і Пташиний (рис. 3,б) та, відповідно, отримано площі всіх типів біотопів (табл. 1).

Таблиця 1. Площі острова Великий Північний та Пташиний у км², отримані в ході розпізнавання космічного знімку QuickBird станом на 2017 р.

\begin{tabular}{|l|l|c|c|}
\hline № & \multicolumn{1}{|c|}{ Типи виділених ландшафтів/біотопів: } & о. Великий Північний & о. Пташиний \\
\hline 1 & угруповання заплавного лісу & 3,188 & 0,056 \\
\hline 3 & чагарникові угруповання & 0,502 & - \\
\hline 4 & остепнені луки & 3,149 & - \\
\hline 5 & водойми & 0,020 & - \\
\hline 6 & болотисті луки & 0,128 & \\
\hline 7 & антропогенно-освоєні території & 0,139 & - \\
\hline 8 & пісколюбні трав'янисті угруповання & 0,657 & 0,004 \\
\hline
\end{tabular}

Розробка маршруту екологічної стежки на острові Великому Північному. Для збереження ландшафртів пропонуємо створити екологічну стежку на острові Великий Північний (рис. 3, б).
Характеристика маршруту: загальна протяжність 11 км, загальна тривалість - 4 год. На маршруті передбачені місця для спостереження за птахами та вивчення унікальної флори заплавного острова, оглядовий майданчик для фотографування й огляду заплави Дніпра.

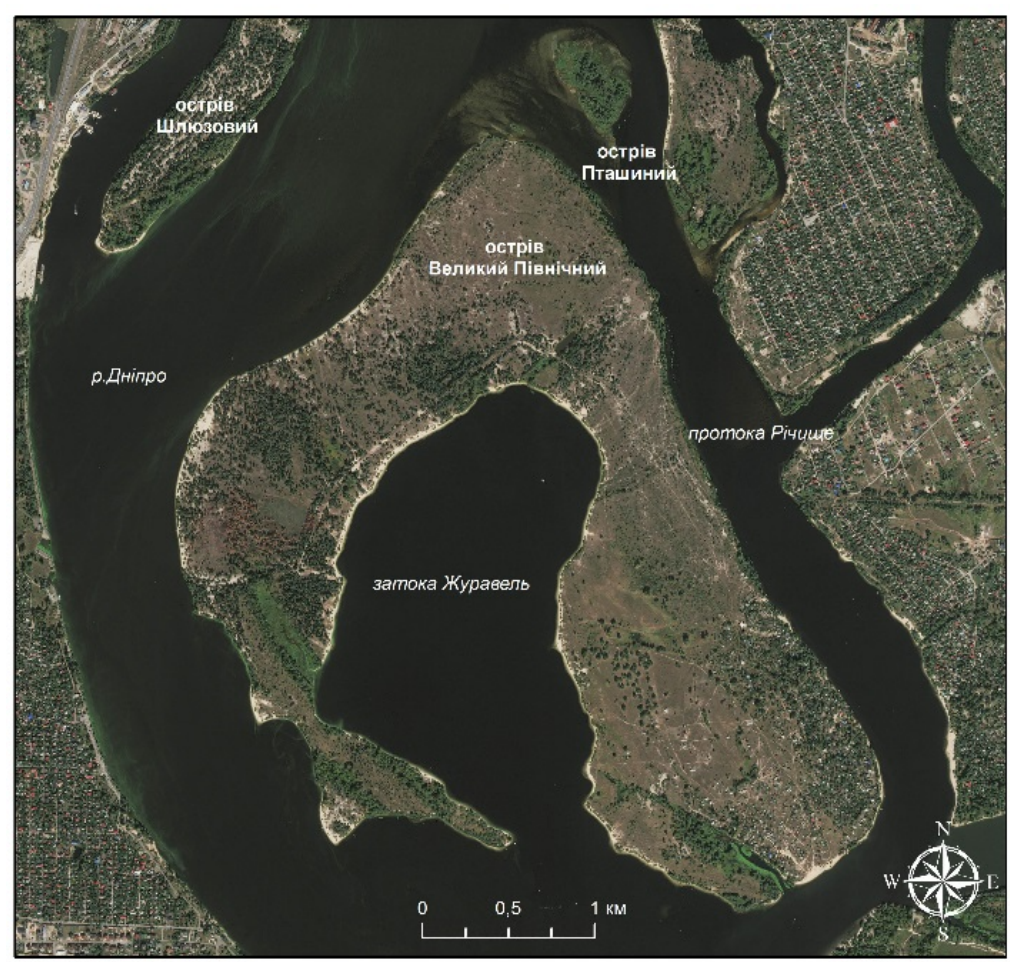

Рис. 3. а) Острів Північний Великий 


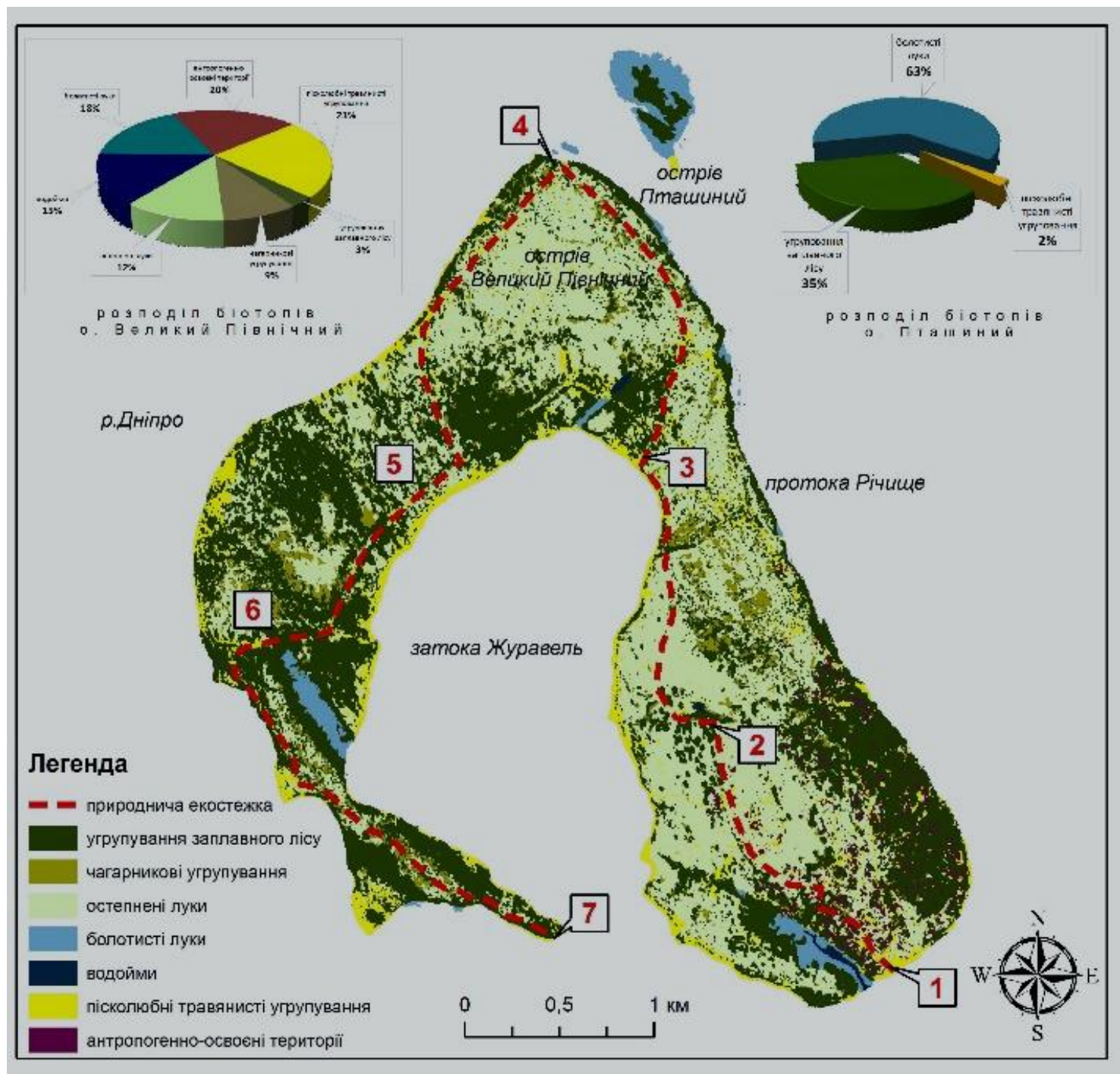

Рис. 3. б) Острів Північний Великий

(a - космічний знімок QuickBird на територію острова;

б - туристична карта з перспективним туристичним маршрутом (екологічною стежкою) островом Північний Великий)

Екостежка включатиме такі об'єкти:

1 - місце початку туристичного маршруту (водна зупинка) "Пристань" поблизу дачного масиву острова;

2 - місце короткочасного відпочинку "Діброва";

3 - об'єкт спостереження "Реліктова затока" (релікти по колишній протоці, яка поділяла острів навпіл) огляд рідкісних лучних рослин острова;

4 - об'єкт спостереження "Старосільський рукав" - огляд о. Пташиний та о. Вальковий (за можливістю, спостереження за птахами);

5 - об'єкт спостереження "Соснове рідколісся" огляд насаджень сосни, які первинно, напевне, були посаджені штучно, утім згодом сосна активно розповсюджувалася самосівом, сформувавши мальовничі рідколісся;

6 - об'єкт спостереження "Затока Журавель" історичний огляд наслідків будівництва житлового масиву Троєщина, коли глибину цієї давньої затоки було збільшено до 10-15 м, також огляд невеликої затоки на західному мисі острова - рештки колишнього озера Запісоччя;

7 - об'єкт спостереження "Вишгородський ріг огляд тополевих заплавних лісів острова.

Сучасний антропогенний вплив на ландшафти дніпровських островів. Пісок, добутий із дніпровських островів, найчастіше використовують для намивання житлових масивів. Ця практика з'явилася в кінці 70-х рр. XX ст., коли було розпочато намивання житлових масивів "Оболонь" і "Троєщина". У 1970-х роках було розпочато намив Оболоні, для цього було піднято рівень ґрунту шляхом намиву, а із 1981 р. - інженерна підготовка забудови Троєщини - гідронамив та спорудження першої черги масиву. Цей процес ми можемо наочно продемонструвати на архівних космічних знімкаx Landsat. Для забудови житлових масивів "Оболонь" та "Троєщина" було використано пісок із північної групи островів (Великий Північний, Труханів) (рис. 4). 


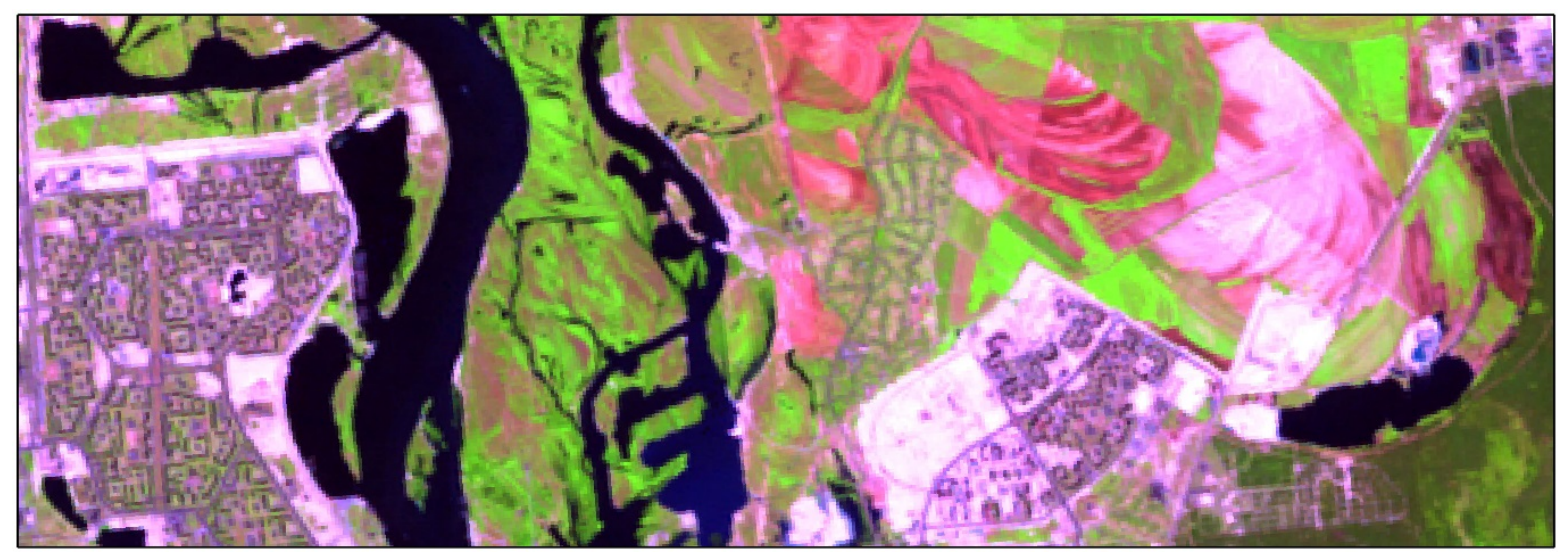

1) Станом на1985 p.

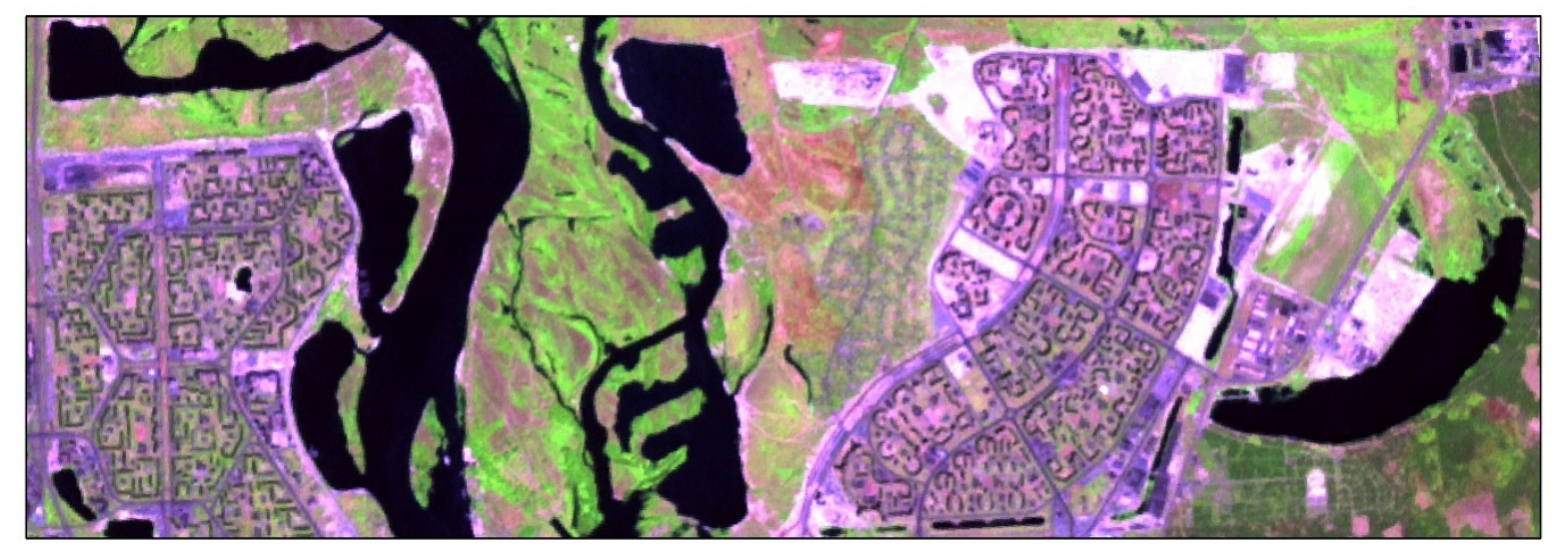

2) Станом на 2000 p.

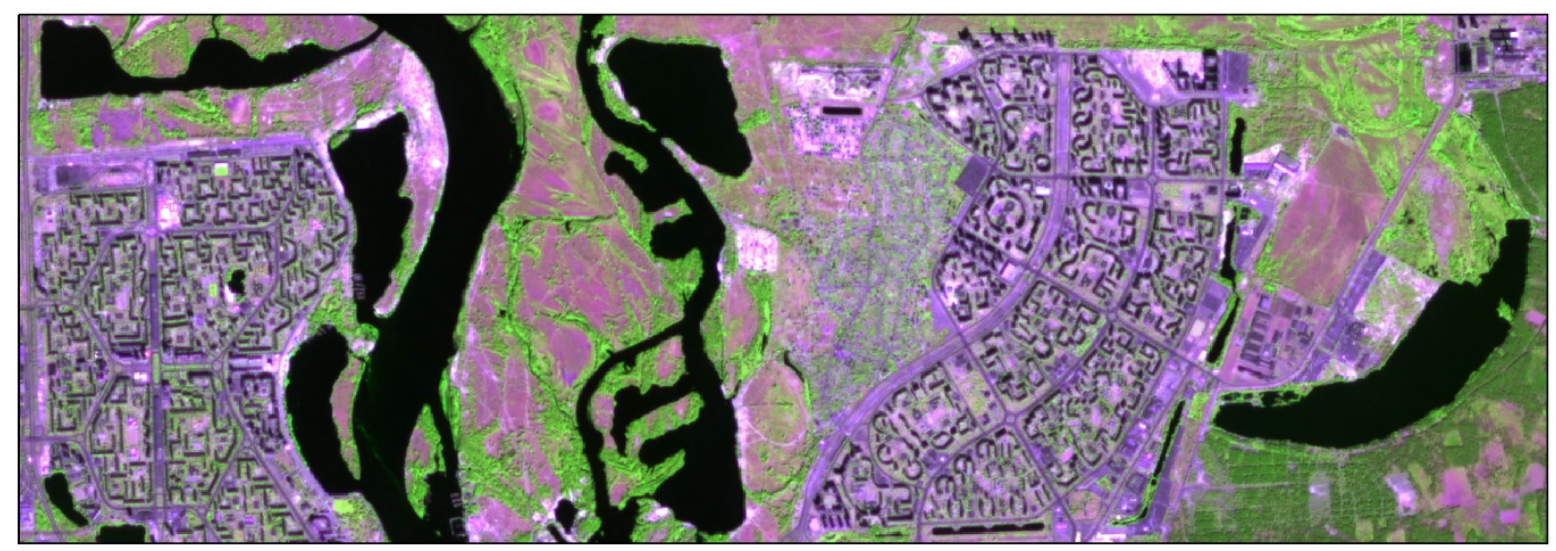

3) Станом на $2017 \mathrm{p}$.

Рис. 4. Приклади намивання піску та зростання забудови північної частини Києва на космічних знімках Landsat із 1985 по 2017 рр. Будівництво житлового масиву Троєщина:

1) 1985 p., 2) 2000 p., 3) 2017 p.

На початку 2000 років було розпочато намивання масиву в районі селища Козин, пісок для цього доставляли із групи південних островів Києва.

Видобування піску призводить до знищення флори й фауни островів, оскільки для видобутку піску потрібно осушувати ділянки. Також надмірний видобуток піску веде до зменшення площі островів, що може призвести до часткового або повного їх зникнення. Отже, на сьогодні головною причиною динаміки зміни площ островів $\epsilon$ видобуток із них піску, що негативно впливає на стійкість біоценозів.
Результати екологічної експертизи островів. Регіональний ландшафтний парк "Дніпровські острови", який займає площу понад 1200 га, було створено у 2004 р. [8].

3 метою здійснення незалежної екологічної експертизи збереження заплави Дніпра експедицією ВГО "Чиста хвиля" за підтримки Посольства королівства Нідерландів в Україні протягом 2006 р. проведено обстеження 35 островів в околицях міста Києва. У результаті виявлені порушення екологічного режиму. Так, для островів Труханів, Долобецький, Гідропарк характерна надлишкова розгалуженість ґрунтових доріг та активний 
рух автотранспорту [3; 5]. Також на островах виявлено наявність: видів, що охороняються згідно з діючим законодавством, екологічно цінних та регіонально рідкісних видів рослинних угруповань, загальне біотичне різноманіття та екологічна унікальність островів.

На островах представлено 18 видів рослин із Червоної книги України, 1 - Європейського червоного списку та 53 види, що охороняються Бернською конвенцією [3; 5].

Отримані результати підтверджують доцільність розширення меж парку "Дніпровські острови". Отже, не викликає сумніву велика ботанічна та природна цінність описаних частин київської заплави. Тому більша частина о-ва Великий (його північна найменш відвідувана частина) та весь о. Вальковський та о. Пташиний мають потрапити у заповідну зону. 15 травня 2017 р. було прийнято проект рішення виконавчого комітету Вишгородської міської ради "Про створення регіонального ландшафтного парку "Пташиний рай", який займає площу 466,8 га та включає острів Великий Північний із внутрішньою затокою Журавель, а також острови Вальковський і Пташиний у межах м. Вишгорода".

Висновки й перспективи подальших досліджень. Порівняння історичних карт та сучасних даних дистанційного зондування дозволило обчислити зміни у площі київських островів за 75 років. Побудована діаграма зміни площ островів наочно показує, що більшість із них суттєво зменшили свою площу. Виявлено, що головною причиною динаміки площ островів $€$ видобуток із них піску, що негативно впливає на біотичну стійкість ландшафтів. Тому для збереження даного архіпелагу треба припинити видобуток піску з метою гідронамиву. У той же час відомо, що надмірний видобуток алювію веде до нестабільності берегової смуги, розмивання берегів.

Результатом дослідження є пропозиція, щодо збереження унікальних природних комплексів заплавних островів актуальна. Одним зі шляхів вирішення проблеми $є$ створення екологічного маршруту та збільшення заповідної зони РЛП "Дніпровські острови".

Результати дослідження можна використати у школі на уроках географії; гуртковій роботі; під час проведення екскурсій. Розроблена туристична картографічна схема острова Північний Великий із екостежкою розширює можливості туристичного пізнання островів р. Дніпро поблизу міста Києва, наочно демонструє й ще раз підтверджує їх природоохоронне значення, що допоможе донести до широких верств громадськості виключну цінність цих територій, визнання їх природоохоронного значення для створення об'єктів природнозаповідного фонду.

Список використаних джерел:

1. Аэрофотосъёмка Второй Мировой Войны (Все оригиналы фотографий, размещенных на этом сайте, принадлежат Национальному управлению архивов и документации (США)) [Електронний ресурс]. Режим доступу до ресурсу: http://warfly.ru.

2. Вишневський В. І. Дніпро біля Києва / В. Вишневський. - К.: Інтерпрес ЛТД, 2005. - С. 1-87.

3. Збереження островів околиць Києва як важливої складової дніпровського екокоридору / Ю. В. Дубровський , Л. Д. Дубровська,
А. Г. Котенко та ін. // Дніпровський екологічний коридор. - Київ: Wetlands international Black Sea Programme, 2008. - C. 78-85.

4. Малець О. Дослідження динаміки змін берегової лінії островів Дніпра в межах Києва (на прикладі острова Великий Північний) / О. Малець, Л. О. Мазуркевич, О. В. Томченко // Вісн. Київ. ун-ту. Географрія. - 2017. - Вип. 1(66) / 2(67). - С. 84-88

5. Онищенко В. А. Острови на Дніпрі у північній та центральній частині Києва // Дніпровський екологічний коридор. - Київ: Wetlands international Black Sea Programme, 2008. - С. 187-190.

6. Парнікоза І. Ю. Київські острови та прибережні урочища на Дніпрі - погляд крізь віки (2016) [Електронний ресурс]. - Режим доступу до pecypcy: http://www.myslenedrevo.com.ua/uk/Sci/Kyiv/lslands.html.

7. Парнікоза I. Ю. Цикл статей про Дніпровські острови // ХайВей: інтернет-видання. - 2005-2012 [Електронний ресурс]. - Режим доступу до ресурсу: http://h.ua/profile/74078/; http://h.ua/story/363755.

8. Про створення регіонального ландшафтного парку "Дніпровські острови". Рішення Київської міської Ради (2004) [Електронний ресурс]. Режим доступу до ресурсу: https://gb.kyivcity.gov.ua/files/project/72/ documents/14770410773713.

9. ЦукановаГ. О. Флористичне та біоценотичне різноманіття островів Дніпра в межах м. Києва та його охорона : дис. ... канд. біол. наук: 03.00.05 / Ін-т ботаніки ім. М. Г. Холодного НАН України. - К., 2005. - 162 с.

10. Цуканова Г. О. Рослинний покрив островів Дніпра в межах м. Києва / Г. О. Цуканова, Т. Л. Андрієнко, О. І. Прядко // Укр. бот. журн. - 2002. - T. 59. - № 2. - C. 135-140.

11. WWII Aerial Photos and Maps (архів оцифрованих копій карт, фотографій та аерофотоснимків, копірованих в основному з оригінапів в Національному архіві США, Бібліотеці США та пожертвування від інших дослідників) [Електронний ресурс]. - Режим доступу до ресурсу: http://www.wwii-photos-maps.com

\section{References:}

1. Aerofotozymka Vtoroi Myrovoi Voinы (Vse oryhynalb fotohrafyi, razmeshchennыkh na эtom saite, prynadlezhat Natsyonalnomu upravlenyiu arkhyvov y dokumentatsyy (SShA)) [Elektronnyi resurs]. - Rezhym dostupu do resursu: http://warfly.ru.

2. Vyshnevskyi V. I. Dnipro bilia Kyieva. - K.: Interpres LTD, 2005. S. $1-87$.

3. Dubrovskyi Yu. V., Dubrovska L. D., Kotenko A. H., Tytar V. M., Tsvelykh O.M. Zberezhennia ostroviv okolyts Kyieva yak vazhlyvoi skladovoi dniprovskoho ekokorydoru // Dniprovskyi ekolohichnyi korydor. Kyiv: Wetlands international Black Sea Programme, 2008. - C. 78-85.

4. Malets O., Mazurkevych L. O., Tomchenko O. V. Doslidzhennia dynamiky zmin berehovoi linii ostroviv Dnipra v mezhakh Kyieva (na prykladi ostrova Velykyi Pivnichnyi) // Visnyk Kyivskoho universytetu. Heohrafiia. 2017. - Vyp. 1(66) / 2(67). - S. 84-88.

5. Onyshchenko V. A. Ostrovy na Dnipri u pivnichnii ta tsentralnil chastyni Kyieva // Dniprovskyi ekolohichnyi korydor - Kyiv: Wetlands international Black Sea Programme, 2008. - S. 187-190.

6. Parnikoza I. lu. Kyivski ostrovy ta pryberezhni urochyshcha na Dnipri - pohliad kriz viky (2016) [Elektronnyi resurs]. - Rezhym dostupu do resursu: http://www.myslenedrevo.com.ua/uk/Sci/Kyiv/lslands.htm.

7. Parnikoza I. lu. Tsykl statei pro Dniprovski ostrovy // KhaiVei: internet-vydannia. - 2005-2012 [Elektronnyi resurs]. - Rezhym dostupu do resursu: http://h.ua/profile/74078/, http://h.ua/story/363755.

8. Pro stvorennia rehionalnoho landshaftnoho parku "Dniprovski ostrovy". Rishennia Kyivskoi miskoi Rady (2004) [Elektronnyi resurs]. Rezhym dostupu do resursu: https://gb.kyivcity.gov.ua/files/project/ 72/documents/14770410773713.

9. Tsukanova H. O. Florystychne ta biotsenotychne riznomanittia ostroviv Dnipra $v$ mezhakh $\mathrm{m}$. Kyieva ta yoho okhorona : dys. kand. biol. nauk: 03.00.05 / In-t botaniky im. M. H. Kholodnoho NAN Ukrainy. - K., 2005. $-162 \mathrm{~s}$

10. Tsukanova H. O., Andriienko T. L., Priadko O. I. Roslynnyi pokryv ostroviv Dnipra v mezhakh m. Kyieva // Ukr. bot. zhurn. - 2002. - T. 59. № 2. - S. 135-140.

11. WWII Aerial Photos and Maps (arkhiv otsyfrovanykh kopii kart fotohrafii ta aerofotosnymkiv, kopirovanykh $\mathrm{v}$ osnovnomu $\mathrm{z}$ oryhinaliv $\mathrm{v}$ Natsionalnomu arkhivi SShA, Bibliotetsi SShA ta pozhertvuvannia vid inshykh doslidnykiv) [Elektronnyi resurs]. - Rezhym dostupu do resursu: http://www.wwii-photos-maps.com

Надійшла до редколегії 29.10.18

О. Томченко, канд. техн. наук, науч. сотруд.

Государственное учреждение "Научный центр аэрокосмических

исследований Земли Института геологических наук НАН Украины", Киев, Украина,

Л. Мазуркевич, учитель географии,

А. Малец, ученик 11 класса, действительный член МАН,

Русановский лицей, Киев, Украина,

КВУЗ "Малая академия наук учащейся молодежи", Киев, Украина

И. Подлесецкая, канд. геогр. наук, ассист.

Киевский национальный университет имени Тараса Шевченка, Киев, Украина

\section{ИССЛЕДОВАНИЕ ДИНАМИКИ ИЗМЕНЕНИЯ ПЛОЩАДЕЙ ОСТРОВОВ КИЕВСКОЙ ГРУППЫ Р. ДНЕПРА}

Исследование заключается в воспроизведении исторического облика островов Киевской группы Днепра на основе использования материалов аэрокосмической съемки времен Второй мировой войны и современных космических снимков с применением геоинформационных технологий (ГИС). С помощью ГИС и методов дистанционного зондирования (ДЗ3) установлены существен- 
ные изменения площади островов Киевского архипелага в период с 1942 по 2017 ге. Определено, что острова начали уменьшаться вследствие антропогенных изменений (намыв песка), что негативно повлияло на состояние их биотопов. Работа посвящена анализу изменения площадей островов Киевской группы Днепра (16 крупнейших островов) и окрестностей за 75 лет, а также детальному изучению ландшафтной структуры острова Большой Северный и его острова - спутника Птичий, который возник недавно и продолжает интенсивно формироваться. Разработана подробная картографическая схема ландшафтов Большой Северный и новый экологический маршрут.

Ключевые слова: киевские острова, геоинформационные технологии, методы дистанционного зондирования, картографическая схема, ландшафтная структура, экомаршрут.

O. Tomchenko, PhD of Technical Sciences, Researcher

State institution "Scientific center for aerospace researches of the Earth of IGS NAS of Ukraine", Kyiv, Ukraine,

L. Mazurkiewicz, Geography Teacher,

A. Malets, Student Grade 11, active member of MAN,

Lyceum Rusanovsky, Kyiv, Ukraine,

Municipal extracurricular school "Kyiv Youth Academy of Sciences", Kyiv, Ukraine,

I. Pidlisetska, PhD Geography, Assistant Professor

Taras Shevchenko National University of Kyiv, Kyiv, Ukraine

\section{RESEARCH OF THE CHANGE DYNAMICS OF THE AREA OF KIEV GROUP OF ISLANDS OF THE DNIEPER}

The study is based on the reconstruction of the historic appearance of the Kiev group of islands of the Dnieper on the basis of the use of archival and modern aerospace materials. The purpose of the study is the justification for the introduction of the protection regime for the Kiev group of islands of the Dnieper that are under greater human impact. To preserve landscapes the Velykyy Pivnichnyy Island, an ecological pathway is proposed and the landscape map scheme of the the Velykyy Pivnichnyy Island is developed on the basis of the application of geoinformation technologies (GIS) and Earth Remote Sensing (RS) techniques.

Mapping the historical reconstruction of the old Dnipro's riverbed allowed displaying the historical look of the Dnipro River to the formation of a reservoir. During the study, the significant changes in the area of the Kiev archipelago's islands in the period from 1942 to 2017 were installed. Determined that the islands began to decrease as a result of anthropogenic changes (alluvial sand), which negatively affected the state of their biotopes. The work is devoted to the analysis of area changes in the Kiev group of islands of the Dnieper (16 largest islands) and environs for 75 years and to the detailed study of the landscape structure of the Velykyy Pivnichnyy Island and its island - the satellite Ptashyny that emerged recently and continues to intensively form.

A detailed cartographic scheme for the landscapes of the Velykyy Pivnichnyy Island is created and a new ecological pathway is developed.

Keywords: Kiev islands, geoinformation technologies, remote sensing methods, cartographic scheme, landscape structure, ecological pathway. 